\title{
Voz de Angola em Tempo de Ultimato
}

Aida Freudenthal

\section{Resumo}

Se o Ultimato constituiu o incidente diplomático mais desgastante no longo da história das relações luso-britânicas, denunciando a reformulação, por ambas as partes, da estratégia expansionista no sul do continente africano, interessou-nos investigar a projeção desse incidente em Angola, bem como o real impacto do mesmo sobre diferentes estratos sociais, quer africanos, quer europeus. A análise dos discursos produzidos, na oportunidade, por governantes, colonos e "filhos da terra", a propósito da verdadeira essência do domínio colonial, mas também dos limites da colonização portuguesa, possibilitou a detecção não apenas das divergências fundamentais, como de opiniōes convergentes quanto ao futuro do território. Se na verdade o Ultimato não se revelou ali decisivo enquanto fato político, o ano de 1890 tornar-se-ia um marco simbólico na emergência de formulaçôes proto-nacionalistas em Angola.

Palavras-chave: Ultimato inglês; fronteiras coloniais; "filhos da terra"; autonomia; imprensa angolana. 
Aida Freudenthal

\begin{abstract}
Angola's Voice at the Time of the Ultimatum

Considering that the Ultimatum was the most abrasive diplomatic incident in the history of Portuguese-British relations, denouncing the reformulation by both parties of the expansionist strategy in the south of the African continent, the author became interested in investigating the reaction of this incident in Angola as well as its real impact on the various social strata, both African and European. The analysis of talks given by authorities, colonists and "native children" on the true essence of colonial domination and also on the limits of Portuguese colonization led to detecting not only basic divergences but also converging opinions regarding the future of the territory. Even if the Ultimatum did not in fact turn out to be decisive although a political fact, the year 1890 was to be a symbol in the emergence of the proto-nationalist formulations in Angola.
\end{abstract}

Keywords: British Ultimatum; colonial borders; "native children"; autonomy; Angolan press.

\title{
Résumé
}

\section{La Voix d'Angola en Temps d'Ultimatum}

Si l'Ultimatum a débouché sur l'incident diplomatique le plus détériorant au long de l'histoire des relations luso-britaniques, révélant, chez les deux camps, un changement de leur stratégie expansionniste au sud du continent africain, il nous a paru intéressant d'examiner les retombées de cet incident en Angola, ainsi que l'impact effectif qu'il a eu sur différentes couches sociales africaines ou européennes. L'analyse des discours produits à l'occasion par les dirigeants, colons et "enfants du pays" à propos de la véritable essence de la domination coloniale ainsi que des limites de la colonisation portugaise, a permis d'isoler non seulement des divergences fondamentales mais aussi des avis convergents sur l'avenir du territoire. Si, en effet, l'Ultimatum ne s'y est pas avéré décisif en tant que fait politique, l'année 1890 est pourtant devenue un jalon symbolique dans l'émergence d'expressions protonationalistes en Angola.

Mots-clé: Ultimatum anglais; frontières coloniales; "enfants du pays"; autonomie; presse angolaise.

Estudos Afro-Asiáticos, Ano 23, no 1, 2001, pp. 136-169 


\section{Introdução}

$\mathrm{E}$ xaltados os ânimos populares e partidários em Portugal, em conseqüência do Ultimato caíram governos e foram proferidas declarações de profundo sentido patriótico, reafirmando as virtudes nacionais, entre elas o esforço civilizador dos portugueses na África. Políticos, escritores e jornalistas exprimiram a indignação que abalou alguns setores da sociedade no ano de 1890 , dando relevo à questão africana no quadro político-partidário nacional.

A investigação histórica tem demonstrado que, nas duas últimas décadas do século XIX, o choque dos imperialismos britânico e português constituiu um episódio fundamental na história portuguesa. De fato, à medida que os governantes esboçaram novas estratégias de exploração e ocupação colonial, buscando alianças no quadro das relaçôes internacionais, a coincidência parcial de objetivos no âmbito dos respectivos projetos imperialistas para a África conduziu ao confronto declarado entre as duas potências aliadas. A contestação, em Portugal, da supremacia colonial inglesa, proveio de fortes resistências emanadas dos setores das burguesias comercial e industrial, para quem a reserva dos mercados coloniais e a proteção pautal tinham se tornado indispensáveis.

Com a finalidade de contrabalançar a influência britânica nesse contexto, Portugal estreitaria relações diplomáticas com a Alemanha, atribuindo maior visibilidade às questóes territoriais $\mathrm{e}$ comerciais do diferendo luso-britânico que conduziria ao Ultimato de 1890 .

Assim como outras potências com pretensões coloniais, Portugal preparava-se para assegurar o seu domínio nos territórios africanos, muito particularmente em Angola. No quadro colonial, desde a defesa de interesses econômicos privados face à concorrência européia, à iniciativa e apoio a expediçóes de reconhecimento geográfico, econômico e político realizadas a partir dos anos 1870 , vários foram os sinais decorrentes da integração progressiva da colônia no conjunto mais vasto do império português na África.

Estudos Afro-Asiáticos, Ano 23, no 1, 2001, pp. 137-169 
Aida Freudenthal

Sabendo-se, contudo, que uma parte substancial das medidas aplicadas localmente dependia das decisões tomadas no Terreiro do Paço, não surpreende o desconhecimento, ou o menosprezo, da especificidade africana que as mesmas denunciam. Por este motivo, e apesar das limitações que caracterizam as fontes de que dispomos, impóe-se proceder a uma análise atenta de uma realidade até hoje mal conhecida. Com efeito, ao envolver povos e culturas muito diversos, a atuação do poder colonial só será entendida se for considerada a dimensão africana da partilha, analisando o curso dos acontecimentos no espaço que era objeto das ambições imperialistas.

A partir deste pressuposto, importa inquirir sobre a realidade que se vivia em Angola, onde a intervenção européia deixara algumas marcas pouco profundas ao longo da faixa litoral atlântica. Assim sendo, e porque a colônia recebia o eco, tantas vezes amortecido, dos conflitos europeus, tentaremos evidenciar a sua incidência na realidade local, na década que antecedeu o Ultimato, e em um contexto que, embora condicionado pela estratégia européia, não deixou de refletir o choque das forças econômicas e sociais que ali coexistiam.

Posto isto, importa averiguar se as questôes internacionais, mormente as questôes de fronteira, seriam entendidas, em Angola, da mesma forma por europeus e africanos.

É, hoje, consensual o reconhecimento de que, na perspectiva dos africanos, a maioria dos tratados assinados não implicavam perda de soberania, sendo entendidos apenas como acordos de cooperação e auxílio (cf. Isaacman e Vansina, 1987:57.1).

Por outro lado, sendo os acordos de fronteira o produto da negociação entre as potências européias, alheias às considerações de ordem etnocultural ou política no que respeitava à realidade africana, no término de um processo conduzido por europeus, viram-se os africanos despojados das suas identidades políticas, juntamente com a derrocada dos últimos Estados independentes da África austral.

De que modo os projetos coloniais portugueses encontravam eco junto a uma população tão heterogênea? Para tentar esclarecer esta questão, importa analisar as atitudes que as populações africanas manifestavam face à pressão crescente da administração e ao reforço do dispositivo militar. Por outro lado, quais eram as perspectivas de futuro formuladas por vários setores de opinião da sociedade colonial? Integração no império português e conseqüente aceitação da lei e da ordem vigentes, perpetuando abusos e violências há muito experimentados? Resistência pelas armas sem-

Estudos Afro-Asiáticos, Ano 23, no 1, 2001, pp. 138-169 
pre que os termos da dominação ultrapassassem limites toleráveis? Ou existiriam outras opçōes?

Pretende-se, com este estudo, contribuir para o esclarecimento destas questôes, identificando registos diferenciados da realidade colonial, através das leituras da mesma, feitas pelos mais destacados elementos da elite urbana da colônia. A diversidade de respostas organizadas em âmbitos individual ou coletivo, possibilitará o confronto de posiçôes diferenciadas perante o colonialismo português nos finais do século XIX.

No vasto meandro de motivações pessoais, distinguem-se necessariamente os condicionalismos que as estruturas sociopolíticas impunham à mencionada elite. Esboçavam-se, afinal, entre os angolanos, os argumentos que viriam a constituir a "voz de Angola", clamando pelos seus direitos e afirmando a identidade de um grupo face ao domínio colonial, argumentos esses que se reproduziriam, no essencial, até ao surgimento do nacionalismo angolano no presente século.

\section{A "Coutada Lusitana”}

"Os principais estabelecimentos são tantas ilhas perdidas num oceano indígena sem limite [...] é pois preciso confessar tristemente que o nosso império no interior é imaginário".

Almeida e Albuquerque (1877)

"A colonização deve começar pelo litoral e depois avançar para o centro". J. Duarte d'Almeida (1878)

"Inglaterra é falsa e desleal nas suas relaçôes internacionais".

Jornal de Mossâmedes (1890)

\subsection{A situação interna nos anos 1880}

A partir dos anos 1870, os imperialismos britânico, francês, belga e alemão, através da sua movimentação comercial e política no centro-oeste africano, foram os intervenientes decisivos na aceleração da partilha da África, da qual Portugal participaria como parceiro indispensável, porém sob o estigma de pequeno país periférico.

Apesar dos condicionalismos internos, a política colonial portuguesa vinha sendo obviamente condicionada por fortes pressões internacionais que repercutiram em Angola ao longo do século XIX. Se até aí a relação de parceria comercial protagonizava as relações entre africanos e europeus, a partir dos anos 1880 tornou-se imperioso para estes delimitar "esferas de influência" e estabelecer

Estudos Afro-Asiáticos, Ano 23, no 1, 2001, pp. 139-169 
relações de "protetorado" sobre as unidades políticas existentes na região, como passo decisivo na afirmação da supremacia européia.

$\mathrm{Na}$ seqüência do processo de partilha, a Conferência de Berlim viria a delimitar a Bacia Convencional do Congo, assegurando nela o comércio "livre" internacional e, desse modo, abrindo caminho à concorrência entre os agentes comerciais presentes na região. Como resultado destas definições, os políticos coloniais consideraram urgente o reforço da autoridade colonial, a fim de fazer respeitar os direitos adquiridos, bem como a liberdade de trânsito para as mercadorias européias e africanas (cf. Brunschwig, 1971:43-45).

$\mathrm{Na}$ seqüência das tendências assinaladas nos séculos anteriores, os interesses comerciais portugueses constituíram o fator de maior peso na definição das prioridades da política colonial no último quartel do século. Induzido, na realidade, pela procura externa de borracha, marfim e cera, o mercado colonial em Angola experimentou intensa atividade, desenvolvida por sertanejos e negociantes do litoral e do interior, tanto africanos como europeus, sendo notável a intensa concorrência que marcou o período em estudo. Alguns efeitos dessa concorrência levaram Oliveira Martins a afirmar, em 1885, que "o comércio de Angola fazia-se em prejuízo do comércio português” (apud Selvagem e Galvão, 1953, vol. II:106.), ${ }^{1}$ já que numerosos agentes comerciais estrangeiros transtornavam o afluxo das mercadorias aos portos da colônia, encaminhando-as para outros portos situados no Baixo Congo.

De fato, os africanos haviam constituído, ao longo dos séculos XVIII e XIX, um sistema de trocas baseado em rotas que controlavam, evitando, na medida do possível, a passagem pelas regiōes sob domínio das autoridades coloniais. Como exemplo, a região ao norte do Ambriz, para onde afluíam os gêneros do interior que eram permutados por peças de algodão, armas e outros produtos, a preços muito mais baixos do que nos portos que estavam sob o controle dos portugueses. ${ }^{2}$

Em resposta a esta situação, a expansão territorial retomada pelos portugueses nos anos 1880 , foi orientada no sentido de assegurar o desenvolvimento da permuta, o acesso mais fácil às áreas produtoras e a correlativa segurança das rotas sertanejas (cf. Wheeler e Pélissier, 1978:65-68.). Essa opção expansionista afigurava-se a mais adequada para enfrentarem a iniciativa concorrencial de outros países europeus, ${ }^{3}$ fazendo ressaltar a urgência de intensificar o reconhecimento de novos mercados abastecedores. Nessa linha, foram concretizadas, por exploradores portugueses, as expe-

Estudos Afro-Asiáticos, Ano 23, no 1, 2001, pp. 140-169 
diçôes que proporcionariam, finalmente, informação sistemática acerca de povos e regióes que, apesar de contatos seculares, permaneciam obscuros para os europeus.

Após os reconhecimentos feitos por Serpa Pinto, Capelo e Ivens, na década de 1870, inseridos em uma estratégia ditada, em larga medida, por pressão internacional, abriram-se novas oportunidades à iniciativa oficial e aos interesses locais. Com efeito, na perspectiva de comerciantes mais antigos e experimentados da colônia, existiam prioridades econômicas e políticas que aconselhavam a organização de expediçôes a regiōes ainda mal exploradas do ponto de vista comercial, onde a penetração dos portugueses não se encontrava assegurada, retardando, desse modo, o acesso a gêneros tropicais bem cotados no mercado mundial.

Através da Sociedade Propagadora dos Conhecimentos Geográfico-Africanos (SPCGA), fundada em Luanda em 1880, os interesses mercantis na colônia mostravam-se muito atentos ao processo político em curso, orientando-se para regióes vitais à intensificação do comércio colonial. ${ }^{4}$

É conveniente determo-nos, um pouco mais, na questão da concorrência localizada em regióes de fronteira, constituindo uma ameaça constante à "coutada lusitana” (Pélissier, 1986, vol.I:54), geradora de uma nova estratégia por parte do poder colonial. Não é demais realçar, de um modo muito preciso, que da perspectiva dos políticos coloniais, importava, em especial, defender interesses comerciais estabelecidos desde longa data, impedindo simultaneamente a instalação de novos concorrentes europeus no espaço que os portugueses reclamavam para si.

Vejamos, pois, a correlação existente entre os interesses comerciais e as decisóes políticas que o poder colonial adotou, considerando as regiōes-problema onde, no lapso de tempo decorrido entre a Conferência de Berlim e o Ultimato, se detectam incidentes concorrenciais que, independentemente das prioridades locais, determinaram os planos de ocupação.

\subsection{A questão do Zaire}

A expansão do domínio europeu na região do Zaire levou ao confronto entre os interesses estabelecidos na região desde longa data e os planos imperialistas mais recentes.

Nesse contexto, Portugal optou, no norte da colônia, por uma política agressiva relativamente ao reino do Congo: foi envia-

Estudos Afro-Asiáticos, Ano 23, no 1, 2001, pp. 141-169 
do o missionário católico António Barroso, em 1881, com o intuito de contrabalançar a influência da Missão Batista inglesa, instalada em São Salvador em 1879; na oportunidade, ele foi também um agente político junto do rei do Congo, sendo incumbido de controlar a sua ação e de conseguir o seu reconhecimento como súdito do rei português (Ferreira do Amaral apud Angolana, 1968, v. II:702; Pélissier, 1986, v. I:246-48).

Após o tratado do Zaire, firmado entre Portugal e Inglaterra em 1884, pelo qual a região entre os Paralelos 5 e 8 era cedida a Portugal, o desacordo dos alemães conduziria à convocação da Conferência de Berlim (1884-85). Na seqüência das suas resoluçōes, a fixação da nova fronteira norte de Angola, em 1885, correspondeu, em parte, aos planos econômicos e políticos formulados para a região pelo poder colonial (Pélissier, 1986, v. I:251-52; 257-61), ao mesmo tempo em que se cumpriam as decisóes de Berlim quanto à instalação do poder efetivo dos belgas sobre a região, no âmbito do Estado Livre do Congo.

A reformulação da estratégia portuguesa visava garantir acesso às rotas que os africanos utilizavam na região do Baixo Congo, nomeadamente a rota do marfim entre Stanley Pool, Ambriz e Quissembo, que passava por São Salvador, e onde predominava a influência de casas comerciais inglesas. Uma outra rota ligava São Salvador ao estuário do Zaire, onde a concorrência entre os entrepostos europeus não era menor. Com efeito, a importação dos algodões de Manchester, das espingardas inglesas e alemãs e do álcool alemão e inglês respondia à procura africana, limitando-se os comerciantes portugueses a fornecer peixe seco, aguardente de cana e pólvora para a permuta.

Renunciando à margem direita do rio em favor da Bélgica, Portugal conservou, no entanto, Cabinda e Molembo, e viu reconhecida, pela Conferência de Berlim, a soberania sobre Cacongo e Ambriz (1885) e todo o território da Costa Norte até Cuango (ibidem:255-56).

Ficou, deste modo, aberta a via para o comércio colonial controlar as rotas do norte, condição que se revelaria particularmente proveitosa durante o boom da borracha, no sentido de assegurar, a partir de 1886, o afluxo de grandes cargas deste produto ao litoral.

Simultaneamente, a região do Bembe - onde existira, nos anos 70, uma exploração de cobre malsucedida - voltou a atrair os interesses econômicos devido à alta do cobre nos anos $80 . \mathrm{Na}$ oportunidade, Luanda procurou obter a colaboração do Dembo

Estudos Afro-Asiáticos, Ano 23, no 1, 2001, pp. 142-169 
Ambuíla, a fim de permitir que na regiāo se procedesse novamente à exploração das minas, assim como à permuta do café, ${ }^{6}$ ao mesmo tempo em que era construída uma estrada que ligaria São Salvador a Bembe, Encoge e Ambriz.

\subsection{A fronteira leste}

$\mathrm{Na}$ multiplicidade de iniciativas imperialistas, não só a fronteira norte congregava as atenções da administração colonial portuguesa. Fora, com efeito, em direção às terras do leste que o projeto imperial português produzira o "sonho cor-de-rosa", baseado em um plano utópico datado dos finais do século XVIII, no sentido de ligar a costa atlântica ao Índico, através da hegemonia comercial portuguesa (cf. Santos, M., 1978:191). No início da década de 80 , no vasto território que integrava o império lunda (ainda praticamente desconhecido dos europeus), os contatos comerciais dos africanos com as margens do espaço colonial processavam-se regularmente: atravessando o Cuango, vindos de leste, súditos do império lunda afluíam a Cassanje e Malanje, com marfim, cera e escravos. Também os comerciantes de Pungo-Andongo e do Bié negociavam com Lunda, embora a permuta de gêneros e mercadorias importadas se encontrasse ainda sob o controle dos africanos.

Abertas novas rotas para o norte através da navegação a vapor nos rios Zaire e Cassai, de responsabilidade de belgas e alemães, as autoridades portuguesas teriam de traçar, para a década de 80, uma estratégia de aproximação com os mercados do interior do Continente.

Constituído prematuramente o distrito da Lunda, a sede permanecera em Malange, sendo o limite leste da colônia, ainda em 1884, o Rio Cuango. Embora a expansão comercial para leste se desse em um ritmo lento, a cidade tornou-se, na década de 80 , um centro, para onde afluíam os viajantes e comerciantes, mormente os alemães Buchner, Pogge e Wissmann, que receberam apoio dos irmãos Machado, ali residentes há muitos anos. Também Silva Porto, acompanhado por pombeiros - comerciantes que percorriam o interior -, chegara a percorrer a região central do Continente, atingindo, em 1881-2, pelo Cassai, a região dos Baluba (ibidem:260 e 338.) apresentando, posteriormente, um plano de exploração científica e comercial à Sociedade de Geografia de Lisboa. 
Aida Freudenthal

Ainda em março de 1882, a SPCGA de Luanda propunha ao G. G. o envio do Major Henrique de Carvalho com os negociantes Saturnino e Custódio Sousa Machado, profundos conhecedores da região a leste de Malanje e da própria Mussumba, em uma viagem de interesse mercantil a Cacheche, região do Cuango famosa pela riquíssima feira de marfim que ali se realizava. A iniciativa dos irmãos Machado levá-los-ia, com efeito, ao Lubuco, em 1883, dirigindo uma comitiva de cerca de duas mil pessoas (União Africo-Portuguesa, 6/5/1882; Pélissier, 1986, v. I:353-55).

Revelou-se, deste modo, a urgência da nova política expansionista para leste: por um lado, foi iniciada a construção da linha férrea de Luanda a Ambaca; por outro, dando continuidade às anteriores viagens de Rodrigues Graça, de Silva Porto e dos irmãos Machado, a relação dos portugueses com o império lunda seria consideravelmente ampliada, através de uma missão diplomática que procuraria contrabalançar a expansão do novo Estado Livre do Congo, ao exigir de Muata Yanvo um tratado de amizade e comércio, e a aceitação da presença de um "residente político" português (Santos, M., 1978:322-23).

Quando o projeto finalmente se concretizou, foi possível a Henrique de Carvalho reunir, durante quatro anos, informação sem precedentes sobre Lunda e áreas limítrofes. ${ }^{7}$ Além da vasta informação recolhida entre 1884 e 1887, que possibilitou a elaboração do estudo etnográfico mais completo que existe sobre a região, ele teve oportunidade de estabelecer contato com autoridades que lhe deram a entender a natureza das instituições do império lunda. Neste contexto, a expedição de Henrique de Carvalho, além do alto valor etnográfico de que se revestiu, elucidou as tensões internas existentes na época entre os lunda e os tshokwe, tendo o explorador testemunhado o declínio do poder do Muata Yanvo na década de 80 , quando os tshokwe tomaram posse da Mussumba. O desmembramento do império, resultante da quebra da relação tributária que algumas províncias mantinham com o poder central, proporcionou a assinatura de tratados entre alguns chefes balunda e o governo português (Pélissier, 1986, v. I:354-55; Santos, M., 1978:191).

De fato, na seqüência da expedição, já em finais de 1889, o governo colonial exigia a aceitação explícita, por Muata Yanvo, do protetorado português - "como negócio de importante alcance político" (AHU Angola, 2aS. 2aR. p. 14, Ofício de 15/2/1890). A pretensão foi facilitada pelo avanço de uma força militar belga até Camaxilo. Desencadeada a questão de soberania na área, Luanda

Estudos Afro-Asiáticos, Ano 23, no 1, 2001, pp. 144-169 
promoveu o envio de uma nova expedição (1890-92), com o intuito de garantir o acesso à região. De fato, o poder colonial considerava vital o controle dos recursos de modo a assegurar importantes rendimentos à alfândega de Luanda (AHU Angola $2^{\mathrm{a} S}$. $1^{\mathrm{a}} \mathrm{R}$. p. 10, Ofícios de 3/12/1889, de 6, 17 e 31/10/1890; 2aS. 2aR. p. 15, Ofícios de 31/3, 21/4, 11 e 15/8, e 4/9/1891), sem os quais se agravaria o déficit financeiro da colônia.

Em 1891, novas fronteiras seriam traçadas e o império lunda foi desmembrado entre portugueses, belgas e ingleses. A efetiva ocupação da região a oeste do Cassai prolongar-se-ia, no entanto, até 1927.

Ao sul do distrito de Lunda, alguns milhares de quilômetros separavam as terras de Benguela e Caconda, do Barotse e do Zumbo, no curso médio do Zambeze, a meio caminho do litoral Índico. Esta rota do leste era efetivamente controlada por mercadores bienos (mambari, como eram então designados) cujas comitivas atingiram dimensão proporcional ao importante papel comercial que desempenharam na África Central até o início do século XX. Seus parceiros, mas também concorrentes comerciais desde os anos 50, foram os pombeiros e sertanejos de Angola (Wheeler e Pélissier, 1978:65-7), cujos percursos deviam conformar-se com as imposições das autoridades africanas, sob a forma de tributos e prestações várias. Ainda não eram reconhecidas, na época, as fronteiras que o colonialismo viria a impor, quando a navegação a vapor e a via férrea tornassem obsoletos os antigos itinerários (Santos, M., 1978:260).

Embora a intervenção da administração colonial na região fosse incipiente, o reino do Bailundu acolhera algumas congregações cristãs, com a instalação de missionários americanos a partir de $1880,{ }^{8}$ após autorização concedida pelo rei Ekui-kui II (1876-1893).

A sua atuação foi, contudo, interpretada por Luanda como denunciando os "projectos de conquista e de assimilação dos padres americanos", ao mesmo tempo em que intrigavam contra a política expansionista portuguesa. Após esforços continuados das autoridades de Luanda, foi só em 1884 que as autoridades africanas admitiram missionários católicos no Planalto (Pélissier, 1986, v. II:68).

Em 1889 manifestou-se uma escalada na corrida dos europeus ao Barotse, região intermédia entre o Bié e o Zumbo, colocando Portugal e Inglaterra em situação concorrencial. Perante os rumores do envio de uma embaixada inglesa à região, o governo

Estudos Afro-Asiáticos, Ano 23, no 1, 2001, pp. 145-169 
português preparou uma expedição porque, segundo afirmava, "era necessário chegar antes" (dos ingleses, entenda-se) por considerar a questão do domínio da regiāo, "muito grave e de um importante alcance politico e nacional.'

Como prelúdio à ocupação, as autoridades de Luanda fizeram acordos com vários sobas. Por um lado, acordos comerciais que dessem preferência à permuta com a colônia de Angola, por outro, acordos políticos para que reconhecessem a soberania portuguesa, colocando os seus territórios sob o protetorado português, admitindo missões religiosas e científicas, e aceitando a instalação de uma força militar (AHU Angola, 2a S. 1ªR, p.10, 1890).

Encarregado de uma missão destinada ao Barotse, Paiva Couceiro deu início, no meio do percurso, à construção de um forte em Belmonte, em 1890, indispondo-se, com essa decisão, com o rei do Bié, Ndunduma, que intimou os portugueses a se retirarem. Nem a mediação de Silva Porto, que habitava a região há décadas, conseguiu demover a autoridade biena, o que levou o sertanejo ao suicídio em março daquele ano. ${ }^{10}$

Apesar da insistência de Paiva Couceiro, a expedição ao Barotse foi interrompida, por efeito do Ultimato, ao mesmo tempo em que os seus efetivos foram encaminhados para o Cubango, a fim de delimitar, nesta região, a esfera de influência portuguesa (AHU Angola, 2a.S 1a.R. p. 10, Ofícios de 13/2, 8/3, 18/3 e $8 / 8 / 1890)$. O território a sul do Zambeze, entre os meridianos 20 e 22, era habitado pelos ambuela e lovale, povos que eram independentes do reino do Barotse, na época governado por Lewanika.

Embora o Tratado Luso-Britânico de 11/6/1891 tenha definido, no seu Arto IV (Santos, M., 1986:153) as esferas de influência respectivas, a ocupação definitiva ocorreria só no início do século XX, na seqüência de ação diplomática e de importantes movimentações militares, empenhadas em eliminar os focos de resistência africanos.

\subsection{A fronteira sul}

Desde a década de 50 as autoridades coloniais portuguesas vigiavam atentamente as terras do sul, alertadas pelas incursóes freqüentes de caçadores e comerciantes europeus no Cunene. No contexto da corrida imperialista ao Continente africano, o receio, mais ou menos fundamentado, do avanço de estrangeiros em regiōes limítrofes do território já ocupado, ainda que precariamente,

Estudos Afro-Asiáticos, Ano 23, no 1, 2001, pp. 146-169 
pelos portugueses, manifestava-se com muita freqüência nos relatórios coloniais, referindo particularmente à fronteira sul.

Serpa Pinto afirmava, em 1878, que

[...] os ingleses protegidos pelo Governo do Cabo, estão já estabelecidos a sete dias de viagem [de Caconda], além do Cunene, no Cuanhama, e têm morto o comércio deste ponto porque apresentam ali as fazendas por metade do preço por que se obtêm em Benguela, monopolizando o comércio do marfim e das penas de avestruz e deixando apenas aos negociantes daqui o da cera e gados cuja permutação se faz só com escravos e é isso o que dá lugar a que Caconda seja uma verdadeira feira de escravatura. (Relatório de 18/1/1878, AHU Angola. CG:48)

Além destas inestimáveis informações sobre as bases da permuta entre africanos e europeus, a par da persistência do tráfico interno de escravos, o explorador registrava a presença de ingleses estabelecidos entre o Cunene e o Cubango, área que era visitada há muito por sertanejos portugueses.

Porém, nem só os ingleses preocupavam Luanda. Na década de 1880, quando despertam os interesses coloniais germânicos, a vigilância das autoridades incidia também sobre possíveis pretensôes da Alemanha em ampliar a sua esfera de influência ao norte do Cunene, nos territórios situados ao norte da catarata de Ruacaná. Segundo Wheeler e Pélissier (1978: 71,74), tinha fundamento esta preocupação, uma vez que as atividades alemãs envolviam, sem dúvida, um vasto plano conspiratório para o oportuno controle da colônia, que implicava exploradores, agentes e homens de negócio, soldados e caçadores, assim como missionários protestantes. Assinado, em 1886, o acordo luso-alemão, ficou delimita$\mathrm{da}$ a fronteira com o sudoeste alemão, sem que, todavia, fossem eliminadas de vez as tensões que renasceriam no início do século XX.

Em parte para intensificar a vigilância na região, o poder colonial procurou reforçar a fixação de colonos, tendo-se registrado, na segunda metade do século XIX, vários fluxos migratórios no litoral de Moçâmedes, bem como no planalto da Huíla. Na maior parte dos casos, porém, o saldo foi o insucesso econômico dos empreendimentos agrícolas e o abandono das tarefas produtivas, em busca de outras ocupações. Para esse insucesso contribuíra a conjugação de fatores como a falta de qualificação específica e a falta de capital, entre outros.

$\mathrm{Na}$ ausência de uma política de colonização coerente, limitara-se o governo de Luanda a receber colonos portugueses, alemães e bôers (AHU, Angola, 2aS. 1aR., p. 15, Ofício de 21/8/1891.), 
manifestando a Lisboa as dificuldades existentes em custear a deslocação, o alojamento e a subsistência nos primeiros meses ( $i b i$ dem). Entendia o governo que o sucesso da colonização dependia mais do número e menos da qualidade dos colonos europeus, incluindo, por isto, grandes contingentes de degredados. Apesar dos planos retomados pela administração, o peso da população portuguesa manteve-se diminuto durante as três primeiras décadas do século XX. ${ }^{11}$

Quanto à imigração estrangeira, principalmente bôer, a administração colonial decidira acolher, no início da década de 1880, uma primeira colônia proveniente do Transvaal. Uma vez obtida a autorização, fixou-se, em 1881, em Humpata, a colônia de São Januário, que em 1890 foi ampliada por novo contingente de recém-chegados, atingindo o total de cerca de 350 homens, mulheres e crianças. Em breve se revelaram novas fontes de conflitos, provenientes da ocupação de terras pertencentes às populaçóes pastoris locais, e ainda devido à colaboração dos bôers enquanto auxiliares das campanhas punitivas e de ocupação contra o "gentio rebelde", como ocorreu no Humbe (Bender, 1980:117-18; 148-49).

Quando a colônia bôer requereu, em 1890 (O Mercantil, 686, 28/9/1882 apud AHU Angola, 2aS.1 ${ }^{\mathrm{a}} \mathrm{R}$. p.10, Ofício de 19/9/1890), subsídios e um código especial para regular autonomamente a vida interna da comunidade, a reação oficial foi claramente desfavorável, a par de manifestas atitudes de xenofobia (AHU Angola, 2a.S. 2a.R. p.14, Ofício de 24/8/1890), pela ameaça eventual que daí pudesse resultar para o domínio português. Estavam criadas as condiçôes para a retirada próxima dos bôers do Sul de Angola.

\section{Angola, a Quem Pertence?}

\subsection{Colonização portuguesa - pró ou contra?}

Alguns anos antes do episódio do Ultimato, processava-se na colônia um debate entre grupos sociais bem distintos, acerca das virtudes/malefícios da colonização portuguesa. Consoante aos interesses individuais, de grupo, de classe, de etnia, eles mesmos variáveis segundo o momento histórico, assim os habitantes africanos e europeus de Angola se posicionaram na década de 1880 perante o poder colonial. Opiniões mais ou menos generalizadas,

Estudos Afro-Asiáticos, Ano 23, no 1, 2001, pp. 148-169 
que uma prática secular de convivência ora pacífica, ora conflituosa, ajudara a sedimentar, assumiram por vezes o caráter de bandeira à volta da qual se congregavam forças econômicas e grupos de pressão. Dentro do núcleo colonial, a profunda diferenciação social transparecia no confronto, ora entre grupos raciais, ora entre interesses regionais ou setoriais.

Em função da heterogeneidade social e racial, obtinha-se níveis de resposta diferenciados entre os habitantes, face à atuação das autoridades coloniais.

Em um outro âmbito, as sociedades periféricas que tinham conseguido preservar, até então, uma relativa independência, ainda que não isenta de restrições e interferências exteriores, estabeleciam relações multiformes com o núcleo colonial, originando conflitos que importa assinalar. Vivia-se, então, no limiar de uma nova fase de expansão do domínio colonial, cujo processo iria obviamente colidir com uma realidade africana sujeita às próprias determinações internas, daí resultando formas extremadas de confronto e violência.

Analisemos, portanto, o posicionamento de vários grupos sociais face à colonização portuguesa na década de 1880 .

\subsection{Os colonos}

Em primeiro lugar consideremos um significativo grupo de pressão constituído por colonos agricultores, comerciantes e pequenos empresários industriais de Luanda, Benguela e Moçâmedes, e o modo como exprimiam a sua opinião sobre as questóes econômicas e políticas que mais os afetavam, em uma fase muito crítica do seu crescimento econômico.

Destinada a suprir as limitaçôes da navegação a vapor no $\mathrm{Cu}$ anza, bem como a carência de carregadores freqüentemente denunciada por agricultores e comerciantes no percurso entre Luanda e Malange, os comerciantes reclamavam, há muito, a construção de uma via férrea entre Luanda e Ambaca. Procedia-se, em meados da década de 1880 , à construção do primeiro trecho, esperando-se, deste modo, o aumento do volume de mercadorias permutadas na região, entre o litoral e o interior. É que, simultaneamente, uma leva de colonos vinha se instalando nas áreas produtivas de cana e de café, associando a exploração agro-industrial ao comércio. 
Aida Freudenthal

No Sul os problemas econômicos eram mais graves e tinham, aparentemente, solução mais difícil. Utilizando a imprensa, especialmente no distrito de Moçâmedes, os colonos mobilizaram fortes campanhas no sentido de influenciar decisões governamentais favoráveis ao desenvolvimento econômico, em particular a instalação da ferrovia, o apoio à agricultura, aos colonos e ao escoamento da sua produção.

Protestando contra a morosidade das decisões, os colonos de Moçâmedes reclamavam que "sem estradas e sem bois de carro para conduzir os produtos ao litoral, não há agricultura que vingue, nem indústria que prospere" (AHU Angola CG p.48, Ofício de $15 / 5 / 1878) .^{13}$

Em uma argumentação mais global, era ainda requerida a urgente construção da ferrovia, em nome do próprio sucesso da colonização: transportar os colonos do litoral para o planalto; promover as explorações mineira e pecuária; escoar os produtos agrícolas e do comércio sertanejo; e efetuar a ocupação militar, constituíam ações das quais o transporte ferroviário parecia indissociável (AHU Ángola, 2aS.2a R. p.14, Ofício de 4/9/1890; Jornal de Mossâmedes, no $164,4 / 8 / 1891)$.

Após o Ultimato, ao longo do ano de 1890, alguns destes argumentos foram reforçados, principalmente por razões de estratégia político-militar, invocando Luanda, por essa razão, a necessidade de proteger a fronteira meridional; defendiam, então, os colonos, a aceleração dos transportes para pacificar "eficaz, segura e menos dispendiosamente e assegurar a ordem e a tranqüilidade nesta região" (Almeida d'Eça apud Jornal de Moçâmedes, no 164, $4 / 8 / 1891){ }^{14}$

Marcados pela dura experiência de uma colonização carente de apoios governamentais efetivos, e às voltas com os freqüentes levantes da população africana, que pretendiam sujeitar, espoliar e explorar abusivamente, como mão-de-obra, os colonos de Moçâmedes, interrogavam-se acerca da capacidade que os governos não revelavam no sentido de promover uma "boa colonização".

Os seus protestos, dirigidos anteriormente contra as disposições emancipadoras da mão-de-obra escrava, voltaram-se, nos anos 1880 , contra os processos de recrutamento instituídos, marcados, aliás, por acentuada ambigüidade, a fim de permitir a perpetuação de práticas escravagistas. Além disso, eram enormes as resistências contra a alteração nas formas de tratamento dessa mesma mão-de-obra, ecoando na imprensa a controvérsia sobre os castigos corporais (varadas) e o serviço forçado (cf., p. ex., Jornal de

Estudos Afro-Asiáticos, Ano 23, no 1, 2001, pp. 150-169 
Loanda, $\mathrm{n}^{\circ}$ s 85 e 87, 8 e 24/12/1880), assim como os protestos contra o agravamento dos custos da mão-de-obra.

Preocupava a eles, além do mais, a precariedade do poder colonial, incapaz de conter as freqüentes revoltas, responsáveis pela perturbação do cotidiano das empresas locais (Jornal de Mossâmedes, $n^{\circ}$ s 155, 17/5/1890; 158, 1/7/1890; 163, 20/9/1890). No seu entender, a incúria e a ignorância colonizadora dos governos só interessaria aos estrangeiros que, no momento oportuno, se apoderariam de Angola, dando "mandado de despejo" a Portugal na sua qualidade de potência colonizadora (idem, $\mathrm{n}^{\circ} 154,1 / 5 / 1890 ; \mathrm{n}^{\circ}$ $163,20 / 9 / 1890)$.

No quadro concorrencial que a atividade dos estrangeiros representava junto às fronteiras, os colonos alertavam as autoridades para as pretensões dos alemães e ingleses, no sentido de responder a eles com o desenvolvimento interno da colônia, uma vez que os "direitos históricos" não bastavam, de modo algum, para assegurar o domínio português.

Com efeito, alguns colonos entendiam que a Alemanha constituía, a médio prazo, um concorrente temível, na medida em que podia criar "sérios embaraços à autonomia colonial" (idem, no 154 , 1/5/1890). Aliás, a aproximação que Portugal promoveu em relação à Alemanha para contrabalançar o predomínio da Inglaterra era vista, na colônia, com reservas e forte apreensão. "Parece à primeira vista que a Alemanha, com a sua expansão em África, indiretamente nos desafrontará do brutal proceder da Inglaterra [...]”, observava um articulista, acrescentando com lucidez que "à Alemanha será fácil provar a incapacidade de Portugal como colonizador em face do estiolamento das suas possessões" (idem, no 159, 15/7/1890), podendo vir a aproveitar-se da vizinhança para se imiscuir na economia de Angola.

$\mathrm{Na}$ perspectiva de alguns colonos mais críticos, importava corrigir a má administração, a letargia do governo, o esbanjamento de fundos, a ingerência abusiva do Estado em todos os setores da vida da colônia, ao mesmo tempo em que devia ser assegurada a exploração dos recursos naturais pelos elementos mais dinâmicos da população. "Parar agora seria morrer [...]" (idem, no 156, $1 / 6 / 1890)$, pelo que preconizavam a maximização das potencialidades econômicas, em especial no Sul, intensificando a pesquisa de recursos, garantindo a manutenção da ordem, praticando uma administração descentralizada a par de uma colonização agrícola em bases sólidas, apoiada na afluência de capitais (idem, $\mathrm{n}^{\circ} 155$, 17/5/1890). 
Aida Freudenthal

Como se vê, não eram, efetivamente, os fundamentos da colonização que eram questionados por este grupo, nem sequer a legitimidade dos processos utilizados. Afinal, estava em questão apenas a eficácia do sistema, do qual os colonos esperavam obter maior retribuição.

\subsection{A "resistência primária"}

Nos finais da década de 1880 , a maioria da população africana, integrada em entidades políticas de dimensões muito variáveis, manifestou outro tipo de resposta ao domínio português em Angola. As relações que mantinham com os núcleos coloniais estavam compreendidas entre dois extremos: a independência ou a sujeição totais, sendo, contudo, as situações intermédias não só freqüientes, como suscetíveis de acentuada instabilidade.

$\mathrm{Na}$ verdade, as pressões exercidas pelas autoridades de Luanda refletiam-se no interior das formações sociais periféricas, atuando no sentido inverso da distância que as separava do núcleo colonial. Deve, por isso, considerar-se que, em função dos interesses prioritários da política colonial, regiōes houve que foram profundamente perturbadas pela intervenção européia, nomeadamente pela procura de mão-de-obra, de mercados e de matérias-primas.

Desse fato, foram conseqüência direta as diversas manifestações de "resistência primária" (Chilcote, 1972:2; Wheeler, 1972:68) provenientes dos sobados ou de reinos independentes, que ocorriam logo que se atingia um ponto crítico em que as relações de compromisso com o núcleo colonial ou seus representantes se rompiam. Eram formas de resistência passiva e/ou ativa que funcionavam como a resposta possível perante situações constrangedoras para aquelas formações sociais.

Ao contrariar global ou pontualmente a interferência política externa, buscavam as autoridades africanas preservar não só a sua soberania sobre os homens e o território legado pelos antepassados, como o controle do produto da terra, a preservação das suas estruturas sociais e o acesso a rotas comerciais e aos mercados abastecedores (cf. Chilcote, 1972:281-82, 293; Isaacman e Vansina, 1987:195-206). Se é certo que a agressividade comercial tanto de africanos (no planalto do Bié e na Bacia do Zaire, por exemplo), como de europeus (sertanejos e outros), produziu alguns episódios de resistência armada, como sucedeu em $1886,{ }^{16}$ não foi esse o domínio mais propício à violência explícita.

Estudos Afro-Asiáticos, Ano 23, no 1, 2001, pp. 152-169 
Foi, pelo contrário, a ocupação de terras férteis ou próprias ao pastoreio, feita pelos colonos europeus em um ritmo acelerado a partir dos anos 70, ${ }^{17}$ que desencadeou os protestos dos seus primeiros possuidores. Essa expropriação, estendida sucessivamente por novas áreas, originou conflitos profundos que em muitos casos persistiriam até ao fim do período colonial.

Por outro lado, a persistência da escravidão na fase terminal do processo abolicionista perpetuou práticas violentas que geravam respostas idênticas às que a condição de escravo ditara durante séculos. As fontes atestam, de modo irrefutável, que perdurou o tráfico interno de escravos, utilizados como moeda de troca, mesmo depois de 1875, ano-limite segundo a legislação abolicionis ta. ${ }^{18}$ Correspondendo a interesses há muito instalados, nem sobas, nem comerciantes, abdicaram de imediato do tráfico. De fato, a rejeição da escravidão provinha quase que exclusivamente daqueles que continuavam a ela submetidos, em atitudes de revolta individual que deixaram sinais nos documentos.

Paralelamente, foi instituído, após 1875 , o recrutamento dito voluntário de "serviçais", expressamente para substituir o anterior processo de angariação de escravos. Pela identidade de processos utilizados, desencadeou resistências renovadas entre as populações sujeitas a prestações coercivas de trabalho em Angola, ao mesmo tempo em que aumentou a exportação de "serviçais contratados" nos anos 80, tanto para São Tomé como para o Estado Livre do Congo, depauperando demograficamente as regiōes fornecedoras. Nesta situação encontravam-se os Conselhos de Novo Redondo, Catumbela, Benguela, Cambambe e Dondo, que contribuíram com o maior contingente de "colonos devidamente resgatados, vacinados e contratados" pela Curadoria, em 1890 e 1891. ${ }^{19}$

Consideremos os níveis de rejeição manifestados pela mão-de-obra africana recrutada em regime forçado, através dos compromissos assumidos pelos sobas perante as autoridades coloniais, e efetivamente compelida a trabalhar nas obras públicas, nas fazendas privadas ou do Estado, nas pescarias etc. ${ }^{20}$ As atitudes mais freqüentemente registradas nas fontes indicam o seu posicionamento perante o sistema que gradualmente absorvia essa mão-de-obra: a lentidão no trabalho, o roubo e a destruição de bens, ferramentas e gado, a fuga dos locais de trabalho, o assassinato de colonos e feitores, são provas eloqüentes da difícil integração dessa mão-de-obra no sistema de exploração por meios coercivos.

Estudos Afro-Asiáticos, Ano 23, no 1, 2001, pp. 153-169 
Aida Freudenthal

Em uma avaliação global, assinale-se que: a instalação de residentes portugueses (civis ou militares) encarregados de fazer imposiçôes às autoridades africanas, quer via negociação, quer militar; ${ }^{21}$ o traçado de fronteiras ao abrigo de tratados assinados entre as potências européias; a cobrança de impostos em nome da Coroa portuguesa, praticada por processos venais; a imposição de prestações de trabalho em jornadas mais ou menos longas e duras; e a ingerência nos processos eletivos das autoridades tradicionais, foram entre outros, fatores decisivos que precipitaram algumas revoltas ocorridas de norte a sul da colônia nesse final de século. ${ }^{22}$ Afinal, a instabilidade que se vivia era produto da contestação evidente da legitimidade da presença portuguesa em Angola, por uma parte significativa dos africanos.

\subsection{A oposição crioula}

Analisemos, por fim, o movimento de conscientização e protesto $^{23}$ desencadeado pelos euro-africanos e negros "civilizados", que constituíam um grupo minoritário na colônia, ainda que predominante em termos sociológicos.

A caracterização desse grupo, já iniciada por Mário António (1961) e Jill Dias (1984), possibilita a compreensão do seu posicionamento político no período em estudo. A sua concentração nas regiōes ao norte do Cuanza e, especialmente, nas cidades de Luanda, Benguela e Moçâmedes, identifica-os claramente como um produto da sociedade colonial. Por outro lado, a existência de laços familiares estreitos entre os elementos do grupo, conferia-lhes uma relativa coesão em torno de alguns valores comuns. Com efeito, a sua integração econômico-social nas estruturas coloniais proporcionara uma síntese de valores culturais de proveniência africana e européia, que conferiam aos indivíduos uma identidade muito particular.

Desempenhando cargos no funcionalismo, no exército, no sacerdócio e no ensino, e ainda como empresários comerciais e agrícolas, detinham o conhecimento da escrita, tendo acesso à informação veiculada pela imprensa periódica da qual alguns eram os principais colaboradores (cf. António, 1961:9-10; Lopo, 1964:65-74; Wheeler, 1972:94-97). ${ }^{24}$

Tendo integrado elementos culturais de origem européia, e identificando-se até certo ponto com uma herança cultural comum, manifestavam uma devoção patriótica a Angola, entidade

Estudos Afro-Asiáticos, Ano 23, no 1, 2001, pp. 154-169 
política, na época circunscrita aos distritos de ocupação colonial. Desse modo, os angolanos sentiam-se distintos das pessoas oriundas do reino (Portugal), e enquanto africanos, também não se identificavam com os "gentios" do interior, em relação aos quais se sentiam culturalmente superiores (Dias, 1984:79).

Embora a elaboração de uma identidade própria dos indivíduos que compunham este grupo tenha sido um processo que se alongou por várias gerações, a sua afirmação cultural situa-se, porém, na década de 1880, quando a voz veemente de Cordeiro da Matta (1857-94), considerado o "pai espiritual" da literatura angolana, emprestou nova dimensão erudita à cultura tradicional crioula. Nessa linha, lutou incansavelmente pela revalorização da herança cultural africana através da legitimação do uso das línguas locais, nomeadamente o kimbundu (António, 1961:33-37; Wheeler 1972:71; Hamilton, 1975:52-54). Embora sendo um escritor de língua portuguesa, Matta fundamentou o seu crioulismo na interpenetração das culturas portuguesa e kimbundu, testemunhada pela própria vivência, assim como a dos seus patrícios angolanos (Dias, 1984:79).

No meio urbano, onde esse grupo constatava que nem a educação, nem as doutrinas igualitárias pregadas pelos missionários eliminavam, por si só, a discriminação social e política, foram-se instalando gradualmente sentimentos de frustração e hostilidade em relação ao poder. Paralelamente, "os filhos do país" verificavam, com indignação, o aumento do racismo e da discriminação, associados à afluência de colonos na década de 1880 (Farol do Povo, no 9 e 11, 7 e 21/4/1883; Muen'êxi, no 1, 2/6/1889).

Numa tentativa de preservar a posição privilegiada que até então detinham, publicaram freqüentes denúncias da violação do seu estatuto e dos direitos adquiridos, enquanto requeriam a Lisboa a proteção dos mesmos, o estabelecimento da igualdade e o fim da flagrante exploração do trabalho dos africanos.

Ao longo dessa luta, os angolanos adquiriram, nesse período, uma consciência cada vez mais profunda da precariedade do seu estatuto dentro do sistema colonial (Futuro d'Angola, 13/5/1882 apud Wheeler, 1972:75, nota 37; Muen'êxi, no 2, 23/6/1889). Neste aspecto, o Farol do Povo, dirigido pelo republicano Arantes Braga, revelou-se o jornal mais intransigente, ao publicar os violentos artigos dos seus colaboradores angolanos. A sua difusão na colônia foi tal que preocupou seriamente o governo, segundo o qual o Farol pregava o "ódio de raça" e aconselhava os cidadãos a rebelarem-se contra a bandeira portuguesa (Ferreira do 
Amaral, "Relatório do Governo" (1883), apud Angolana, v. II). A ação cultural e cívica desenvolvida no último quartel do século por personalidades angolanas, constituiu um movimento essencial à definição da identidade do grupo. Com interesses em diversas áreas, da lingüística à educação, da literatura à etnografia, da filosofia à política, esses angolanos contribuíram para uma elevada consciência da própria identidade, da sua possibilidade de progredir segundo padrôes ocidentais, valorizando simultaneamente a própria condição de angolanos (Hamilton 1975, v. I:53). ${ }^{25}$ Refira-se, ainda, que na década de 1880 o associativismo cultural e político africano, radicado em meio urbano, foi fruto da necessidade inadiável de refletir sobre a "nacionalidade" angolana (Futuro d'Angola, 13/5/1882 apud Wheeler, 1972:75) e de concertar formas de ação que integravam, simultaneamente, questões culturais e políticas. Foi manifestado, nessa oportunidade, o desejo de congregar os interessados em uma associação de "filhos do país", designada União Luso-Africana, a fim de lutar contra as injustiças cometidas pela metrópole e acabar com preconceitos - o "ódio de raça" (Arauto Africano, no 1, 17/3/1889). ${ }^{26}$

Apesar de relativamente homogêneo, este grupo de angolanos que propunha a "nova renascença intelectual africana" ( $O \mathrm{Fa}$ rol do Povo, no 6, 17/3/1883) e que acreditava que a adoção dos padrôes europeus era indispensável para o progresso econômico e social de Angola, perfilhou posições contraditórias relativamente a algumas questôes de "política interna".

Não será excessivo chamar de moderada uma ala composta por angolanos que, não rejeitando a civilização européia, criticavam, no entanto, a colonização portuguesa, tendo como referência outras colonizações que consideravam mais bem-sucedidas. $\mathrm{O}$ modelo do self-government britânico era invocado freqüentemente em nome da "autonomia de governo das colônias, da descentralização e da democracia" (sic).

$\mathrm{Na}$ defesa constante dos próprios direitos, a voz destes cidadãos enunciava os princípios essenciais preconizados pelos teóricos do liberalismo, a saber, a liberdade, a igualdade perante a lei, a educação primária, secundária e profissional, o direito de voto, o exercício de cargos sem discriminaçôes raciais (Uniāo Afro-Portuguesa, n ${ }^{\circ}$ 1, 6/5/1882; Futuro d'Angola, no 79, 15/9/1887; Muen'êxi, no 1 , 2/6/1889; Arauto Africano, no 13, 1889).

A afirmação da própria personalidade jurídica perante o governo colonial não impedia, no entanto, uma certa consonância com as preocupações governamentais: alguns angolanos apelaram

Estudos Afro-Asiáticos, Ano 23, no 1, 2001, pp. 156-169 
à defesa contra os "estrangeiros cobiçosos" e à proteção ao comércio e indústria, ao mesmo tempo em que se revelavam favoráveis à colonização e à instalação de missões que promovessem a "civilização" entre os africanos (Arauto Africano, no 1, 17/3/1889).

Apesar do descontentamento social existente na colônia, e embora reclamando o respeito pelos direitos essenciais dos africanos "civilizados", esta corrente reformista era a favor da integridade do império português e da solidariedade entre as suas partes constitutivas. A maior parte dos seus componentes acreditaria, por certo, que a salvaguarda dos seus interesses econômicos e políticos residia no apoio à repressão às revoltas do "gentio", cuja ação receava. Só isso explica os louvores à atuação, nesse campo, do general Geraldo Vítor, nos anos 1880, da parte dos seus conterrâneos, assim como a defesa, pela comunidade crioula do Dondo, em 1883, da colonização portuguesa (Dias, 1984:84-5). Por outro lado, a identificação com Portugal era simbolizada pelos festejos anuais do 15 de agosto, "o dia dos angolanos", no qual as famílias crioulas de Luanda e Benguela celebravam, com grande entusiasmo, a tomada de Luanda aos holandeses, em 1648, a chamada "Restauração de Angola" (Almanaque de Lembranças 1890 apud Dias, 1984:85).

Entretanto, devido ao agravamento das práticas discriminatórias ao longo da década de 1880 , sustentadas por uma legislação que discriminou os africanos na sociedade colonial, qualquer "filho do país" ficou sujeito à arbitrariedade dos juízes, curadores e outros agentes de autoridade. Agravado o processo de alienação dos seus recursos econômicos e de perda de empregos, a discriminação atingia os angolanos a tal ponto que gerou, entre colonos e africanos "civilizados", um clima de controvérsia permanente, que atingiria a sua fase mais crítica nos anos 1890 (Futuro d'Angola, no 206, 14/6/1894).

A controvérsia conduziu à radicalização de posições da parte de alguns africanos, para quem o simples reformismo já não oferecia qualquer esperança. Entre os defensores de atitudes mais radicais, incluem-se os já anteriormente citados José de Fontes Pereira, Arantes Braga, João Inácio de Pinho e Mamede Sant'Ana e Palma, que foram as consciências mais críticas da situação. Advogavam eles a transformação do status quo colonial, uma vez que "a prosperidade das colônias só principia quando instituída a nação independente" (idem, no 79, 15/9/1887).

Esta perspectiva mais radical quanto ao futuro da colônia, expressa nos anos 80 com clareza e alguma freqüência na imprensa

Estudos Afro-Asiáticos, Ano 23, no 1, 2001, pp. 157-169 
Aida Freudenthal

local, encontrava-se, no entanto, permeada pelas idéias políticas que na época se difundiam em Angola, provenientes da Europa. Optar por um regime republicano era o que o Farol do Povo e o Arauto Africano, porta-vozes desse grupo mais radical, preconizavam, desferindo profundos ataques contra a colonização portuguesa, contra a monarquia agonizante, contra "quatro séculos de escravidão" (Echo de Angola, no 4, 3/12/1881; Farol do Povo, 17/3/1883; Arauto Africano, no 32, 6/1/1890 e no 34, $20 / 1 / 1890){ }^{27}$

Constata-se na época, de fato, uma associação cada vez mais estreita entre o republicanismo e as aspirações mais profundas dos angolanos com relação ao futuro político da sua terra. A proclamação da República brasileira, em 1889, aclamada por uma fração da opinião angolana ( $O$ Desastre, $\left.n^{\circ} 5,15 / 1 / 1890\right)$ terá, decerto, trazido renovadas esperanças aos projetos que alguns acalentavam. Os debates que animaram as suas reuniōes domésticas e associativas, e que transbordavam, por vezes, para as colunas dos jornais, incluíam questões como o trabalho forçado, o despacho coercivo de trabalhadores para São Tomé, o estatuto dos cidadãos angolanos em confronto com os do reino, a falta de escolas e de oportunidades profissionais, as péssimas condições das prisões locais etc. (Wheeler, 1972:76 e 99).

Contra a defesa da função civilizadora dos portugueses, foi, nessa oportunidade, denunciada pelos mais radicais, a "falsa civilização" introduzida em Angola, resultado da atitude obscurantista intencionalmente adotada em relação aos africanos, a quem eram negadas as "luzes", pelo receio de que através do conhecimento "dos seus costumes bárbaros", fossem "capazes de proclamar a independência do seu país" (Futuro d'Angola, 8/4 e 29/4/1882, 10/11/1886; Arauto Africano, no 10, 26/5/1889).

Não se tratava, porém, de uma questão exclusivamente política, já que se detectava o problema subjacente da salvaguarda da sua identidade cultural. Sentindo-se os angolanos na iminência de perderem a sua "nacionalidade" sob a pressão do domínio português, preconizaram em desespero de causa o seu apoio à Inglaterra vitoriana. No quadro da disputa colonial sobre os territórios africanos, o decano dos jornalistas angolanos, José de Fontes Pereira, apresentou a proposta corajosa de que a Inglaterra se assenhoreasse de Angola (Arauto Africano, 20/1/1890). ${ }^{28}$ Este desafio, publicado em 20 de janeiro de 1890 pelo Arauto Africano, seria o mais sério que os angolanos, através do seu representante mais eminente, di-

Estudos Afro-Asiáticos, Ano 23, no 1, 2001, pp. 158-169 
rigiriam contra o poder colonial neste fim de século tão conturbado pelas questôes de supremacia imperial.

Agravando a posição de Portugal como potência candidata a um domínio inconteste sobre os territórios africanos que pretensamente civilizara ao longo de quatro séculos, a crítica, não só insistente como temerária, dos princípios dessa mesma colonização, formulada por uma elite até então beneficiada pelo sistema (Wheeler e Pélissier, 1978:85-6), veio atingir mais uma vez a credibilidade da ação colonial portuguesa.

Apesar de suspeitos de parcialidade induzida pela competição internacional, alguns círculos antiescravagistas geravam denúncias que eram reforçadas no interior da sociedade colonial pelos próprios angolanos, confirmando, deste modo, as seqüelas da administração portuguesa.

Nem os conflitos de interesses entre os colonos do Sul e o poder colonial - traduzidos na crítica à prática administrativa e ao abandono a que eram relegadas as suas iniciativas -, nem os movimentos de resistência dos povos do interior - expressos em revoltas mais ou menos desgastantes para o poder colonial - abalaram tanto a estabilidade desse mesmo poder. A contestação global que as palavras de Fontes Pereira exprimiam, deixava entrever o conjunto de protestos que se avolumavam na última década entre os "filhos do país", cuja função social e política vinha sendo minada por autoridades que visivelmente se preocupavam com outras considerações que não a identidade e a autonomia dos africanos. Neste quadro conflituoso, em que governantes e governados projetavam de modos divergentes o futuro da colônia, importa analisar os dados disponíveis no sentido de averiguar em que medida terá o Ultimato constituído um fator de dissuasão ou de reforço das tendências políticas registradas nos dois campos.

\subsection{O pós-ultimato}

A notícia do Ultimato de 11 de janeiro de 1890 chegou por telégrafo a Luanda. Que eco teve na sociedade colonial esse incidente diplomático, que tanta perturbação trouxe à opinião pública em Portugal ${ }^{29}$ Segundo um relato oficial,

[...] a questão anglo-lusitana produziu, como era natural, a maior indignação entre todos os portuguezes. As manifestações populares que por esse motivo se tem feito em nada tem alterado o socego e ordem publica. A grandiosa ideia de se promover uma subscrição nacional a fim de se organisar meios de defesa marítima encontrou aqui bom acolhimento no

Estudos Afro-Asiáticos, Ano 23, no 1, 2001, pp. 159-169 
Aida Freudenthal

coração dos portuguezes que a abraçaram cheos de enthusiasmo e segundo me consta tem havido donativos valiosos. Os negociantes resolveram cortar as suas relaçôes comerciais com a Inglaterra e muitos suspenderam já pedidos de mercadorias daquela nação. Conquanto pacíficas todas essas manifestações, mas temendo algum excesso ou acto de violência contra a colonia ingleza, foram tomadas as convenientes medidas policiais.

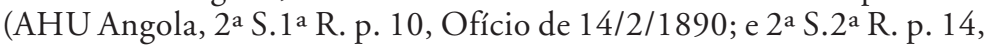
1890)

Nesta apreciação das reações mais evidentes e imediatas ao Ultimato por parte dos portugueses que residiam na colônia, ressalta a sua preocupação em acertar o passo com as grandiosas manifestações que ocorriam no reino. Na seqüência dos protestos nacionalistas, as reuniōes feitas no Theatro de Loanda e na Associação dos Empregados do Comércio da cidade, foram as mais significativas no âmbito das intenções. Na prática, no entanto, seus efeitos foram muito escassos, mesmo entre os colonos (Correio de Loanda, no 13, 6/4/1890; Jornal de Mossâmedes, no 161, 15/8/1890). Senão, vejamos.

Enquanto referência noticiosa, o Ultimato não ocupou grande espaço nos jornais de Angola, nem desencadeou movimentações de algum modo comparáveis às que tiveram lugar no reino ou mesmo entre as comunidades de portugueses na Europa e no Brasil (Teixeira, 1990:120-121). O recolhimento de fundos acabou por trazer escassos resultados. As trocas com a Inglaterra, no movimento comercial referente aos anos que se seguiram ao Ultimato, aparecem pouco afetadas. Os desacatos contra os súditos britânicos residentes na época em Angola, se os houve, não ficaram registrados.

O que, de fato, parece ter produzido maior controvérsia pública, foi o artigo "Partido Colonial", de Fontes Pereira (Arauto Africano, 20/1/1890), cuja publicação levou um grupo de cerca de noventa brancos estabelecidos na colônia a assaltar a redação do jornal e a exigir a retratação do autor. ${ }^{30}$ Este ato intimidatório, além de ter atingido duramente o jornalista angolano, já em idade avançada, terá eventualmente contido outras manifestações antiportuguesas do grupo mais crítico da colonização.

Em um nível mais profundo das consciências, o Ultimato reforçou velhos temores, especialmente junto às autoridades e aos portugueses da colônia, adensando o espectro da ameaça estrangeira: qualquer ato que contestasse, ou pusesse simplesmente em causa a soberania portuguesa em Angola, era suposto ter por trás a mão de algum agente estrangeiro, especialmente britânico. Ou simplesmente se temia, e com alguma pertinência, que qualquer

Estudos Afro-Asiáticos, Ano 23, no 1, 2001, pp. 160-169 
tendência hostil ao domínio português seria de imediato apoiada por uma força estrangeira.

Citemos alguns exemplos. O reino do Bié, no tempo do soba Ndunduma, rebelou-se contra a ingerência portuguesa na região. Segundo a explicação oficial, os incidentes tinham ocorrido "por sugestão de estrangeiros", sendo atribuída grande responsabilidade à missão escocesa de Garanganja, que teria incitado o povo à rebeliāo (Jornal de Mossâmedes, no 155, 17/5/1890; no 157, 15/6/1890; no 160, 4/8/1890). ${ }^{31}$

Acusação idêntica seria apresentada, tempos depois, contra os missionários de Donga, que teriam influenciado um soba cuanhama no sentido de recusar a soberania portuguesa (AHU Angola, $2^{a} S .1^{a}$ R. p.15, Ofício de 21/8/1891). O trauma nacionalista resultante do sobressalto que o Ultimato provocara em alguns setores da sociedade colonial, projetou-se em uma percepção exacerbada de perigos ocultos, assim como em manifestaçōes primárias de xenofobia. Em especial nas fronteiras a leste e a sul da colônia, qualquer sinal de presença estrangeira bastava para originar boatos e atos de prevenção despropositados.

Segundo um editorial do Jornal de Mossâmedes, tanto os assaltos comandados por sobas avassalados, como as invasões freqüentes de hotentotes, que devastavam os campos e capturavam gado, matando também alguns africanos, eram tidos como atos levados a cabo

“[...] por sugestôes de estrangeiros, agremiados em missões, sociedades ou companhias largamente subsidiadas pelos respectivos governos, e que são sempre um foco permanente de conspirações contra o domínio portuguez, quando para se estabelecerem nos pediram a nossa protecção e a nossa licença" (Jornal de Mossâmedes, no 158, 1/7/1890).

A freqüência de apreciações deste teor permite-nos afirmar que o nível de acusações contra os estrangeiros, dentro ou fora da colônia, qualquer que fosse a sua atividade (desde comerciantes a missionários) foi aumentando a ponto de se tornar uma referência obsessiva no discurso nacionalista português. Fora, simultaneamente, encontrada uma explicação que mistificaria, até ao fim do período colonial, a origem das revoltas dos africanos, remetendo-a para o plano da intriga internacional contra o domínio colonial português.

O Ultimato atuou, em um outro plano, como detonador, no quadro da estratégia adotada a partir da década de 1890, em relação às populações africanas independentes da tutela colonial. Um

Estudos Afro-Asiáticos, Ano 23, no 1, 2001, pp. 161-169 
dos efeitos imediatos do incidente luso-britânico foi a aceleração da ocupação militar dos territórios não-avassalados, sempre que a pressão exercida sobre os reis e sobas independentes, no sentido da conclusão de tratados de vassalagem ou submissão ${ }^{32}$ não surtisse efeitos imediatos. Visto que o conceito de ocupação efetiva e o entendimento dos africanos sobre esses tratados, na maior parte dos casos, se contradiziam na sua essência, a situação de conflito só podia intensificar-se (Isaacman e Vansina 1987:54, 57-8).

É fato que algumas revoltas atingiam proporções consideráveis e alcançavam maior duração, graças ao armamento de fogo que os revoltosos conseguiam adquirir com os comerciantes estrangeiros e portugueses, mormente no Sul, por permuta de cabeças de gado que eram conduzidas até ao Cabo e ao Transvaal. ${ }^{33}$

Também é certo que, na colônia, atribuiu-se ao Ultimato responsabilidades pela paralisação de algumas iniciativas em curso, como sucedeu com a ferrovia de Moçâmedes, ao retrair-se o crédito a ela destinado. Algo idêntico ocorreu quando as questôes de política externa chamaram a atenção de políticos e da administração (Jornal de Moçâmedes, no 164, 11/8/1891; no 181, $15 / 5 / 1892)$, relegando a último plano realizações que só a médio prazo seriam rentáveis, ou trariam dividendos políticos aos responsáveis coloniais. Em alguns setores da opinião pública, freqüentemente manipulada pelos governantes, aconteceu que através de análises incorretas dos acontecimentos, remeteu-se para o domínio da política externa a explicação de problemas conjunturais vividos na colônia (cf. Teixeira, 1990:156).

Em outro sentido, contudo, o Ultimato foi entendido como um aviso oportuno aos governantes: o de que a inércia, o desleixo e a ignorância dos governos eram a causa da situação atual (Jornal de Moçâmedes, no 163, 20/9/1890), sendo necessário pôr-lhes um fim o mais brevemente possível.

Por efeito do Tratado Luso-Britânico de 11 de junho de 1891, Portugal preservou o domínio exclusivo de Angola, contra as cessões que foi obrigado a fazer em relação a Moçambique (cf. Alexandre, 1979:63). Na seqüência disso, a reserva do mercado de Angola para os interesses coloniais portugueses iria constituir uma "tábua de salvação" no contexto da recuperação da crise que afetava profundamente as finanças e a agricultura portuguesas. O protecionismo dos anos 1890, traduzido localmente em numerosas medidas restritivas, iria, porém, precipitar na colônia novas ondas de protesto dos comerciantes e agricultores, revelando persistentes

Estudos Afro-Asiáticos, Ano 23, no 1, 2001, pp. 162-169 
contradições face às burguesias metropolitanas e aos governos que as protegiam.

\section{Conclusão}

Apesar da historiografia colonial ter focalizado preferencialmente o Ultimato no quadro da história de Moçambique, por razões de estratégia imperial afigurou-se imprescindível investigar a sua eventual projeção em Angola, como parte integrante do mesmo império.

Existe, no entanto, outra justificação para fazer incidir a atenção sobre Angola na década de 1880 . Foi, com efeito, esse breve lapso de tempo crucial para as populações sobre as quais se implantou gradualmente um domínio formal, adquirindo, então, especial relevo as questões de delimitação de zonas de influência européia, onde as pressões estrangeiras mais se evidenciaram.

Foi esse também o momento em que se manifestaram, no território considerado, obstáculos sérios à concretização das pretensôes portuguesas: de um lado, a concorrência econômica e política das potências imperialistas, transposta para a vasta região por agentes das mais diversas procedências; de outro lado, os movimentos de resistência africana contra a integração a qualquer preço, nos novos espaços determinados por considerações a que os próprios africanos eram totalmente alheios.

Finalmente, foi também essa década crucial para a construção da identidade da população urbanizada de Angola, constituindo um processo que não foi indiferente à luta que mundialmente se desenhava em torno do Continente africano. É importante recordar que a repercussão da partilha em Angola fez avolumar o descontentamento dos "filhos do país", como foi já assinalado por outros historiadores, o qual implicou, na época, um posicionamento muito crítico em relação à colonização portuguesa.

Nunca anteriormente o domínio português em África se revelara tão precário e fora tão questionado. Justamente no momento em que, nos corredores diplomáticos, Portugal procurava legitimar pretensões expansionistas, invocando para tal os esforços desenvolvidos durante séculos (quando a prioridade dos descobrimentos portugueses legitimava os direitos históricos), eram elaborados, em alguns estratos da sociedade colonial, projetos que colidiam com os objetivos da política colonial, ou deles divergiam em absoluto. 
Aida Freudenthal

O futuro desses projetos iria revelar-se no período seguinte, quando se afirmou a intervenção das forças expedicionárias e das forças de segunda linha, demarcando novas fronteiras e abatendo os últimos redutos independentes. A natureza muito diferenciada dos atos de resistência revelou-se com grande nitidez: enquanto uns recorriam à guerra para defender a sua autonomia e a sobrevivência das suas estruturas sociais (no sentido mais amplo), outros utilizavam os meios facilitados por uma vivência multicultural, em que o predomínio da Europa era crescente.

Para estes, a principal arma era a palavra, falada ou escrita; para aqueles, as revoltas eram o meio mais poderoso de manifestar a clara rejeição da presença portuguesa, desde que ela ultrapassasse os limites aceitáveis da convivência. Apesar disso, a correlação de forças internacionais não viabilizou a aliança desejada pelo angolano Fontes Pereira e seus companheiros políticos, nem sequer proporcionou a estes a oportunidade de tomarem nas próprias mãos os destinos da terra-mãe.

A estratégia britânica em África, orientada para as regiōes Sul e Leste do Continente, não levou em consideração essa hipótese, se é que se terá apercebido dela. No entanto, quando a intransigência britânica fez abortar definitivamente o projeto do mapa cor-de-rosa, forçou os responsáveis pela política colonial portuguesa a reconhecerem que não bastava invocar direitos históricos para implantar a autoridade colonial.

A instabilidade interna que se manifestou em simultâneo, conjugada com a pressão internacional, constituiriam fatores decisivos na fase de ocupação territorial que se seguiu entre os anos de 1890 e 1920. Fora esse, afinal, o prelúdio dos confrontos decisivos que tornariam Angola uma colônia de projetos adiados.

\section{Notas}

1. A propósito das dificuldades sentidas, Ferreira do Amaral acusava, no seu Relatório, o comércio de Lisboa de falta de ousadia, ao mesmo tempo em que reclamava o abrigo de uma política protecionista através de pautas (apud Angolana, 1968, v. II).

2. Firmas européias como Daumas Béraud e Conquis Ainé, utilizavam ainda práticas de cambulação, através das quais obtinham lucros substanciais (cf. Ferreira do Amaral apud Angolana, 1968, v. II:685, 717-721).

3. Alguns viajantes visitaram regiōes de Angola, ou circunvizinhas, até a primeira metade do século XIX, como Lacerda e Almeida (1798), P. J. Baptista e Amaro José (1802-11), Monteiro e Gamitto (1831), Rodrigues Graça (1843-46). Registrem-se as viagens de europeus na região durante a segunda metade do século XIX: Magyar

Estudos Afro-Asiáticos, Ano 23, no 1, 2001, pp. 164-169 
(1849-57), Welwitsch (1853-60), Livingstone (1854-57), Bastian (1857), Andersson (Cubango, 1859), Cameron (Bié, 1873-76), Lux e Pogge (Lunda, 1875-76), Schütt (Lunda, 1878-79), Buchner (1879-81) e Wissmann (Lunda 1881-84). Ver Heintze (1999).

4. Sociedade científica, também referida como Sociedade de Geografia de Luanda, fundada em 1880 por cerca de uma centena de sócios entre os quais Henrique Dias de Carvalho, José Baptista d'Oliveira, Felisberto Miranda Júnior, Eduardo Ayalla dos Prazeres, Alfredo Mântua, Francisco de Sales Ferreira, António Urbano Monteiro de Castro. Entre os sócios fundadores, predominavam os oficiais do exército e da armada, os funcionários e os negociantes. Sua atividade parece ter terminado em 1882 (cf. Boletim da SPCGA, 1881).

5. Dos 49 entrepostos existentes no estuário do Congo, 26 pertenciam a comerciantes portugueses, 12 a holandeses, 7 a franceses e 4 a ingleses (cf. Pélissier, 1986, v. I:nota 6).

6. Vários chefes ndembu tinham preservado sua independência, desde a revolta de 1873-76, criando obstáculos à permuta com a colônia. Só em 1890 a administração colonial conseguiu impor autos de compromisso a alguns deles, no sentido de acatarem o poder colonial e reatarem as trocas comerciais. Ver AHU, Angola 2a S. 1a R. p. 10 , Ofício de 5/12/1890.

7. Na mesma época (1884-85), realizava-se a segunda viagem de Capelo e Ivens, uma clara intenção de garantir os direitos históricos para Portugal.

8. Segundo Wheeler e Pélissier (1978:77), às primeiras missões congregacionistas do American Board of Commissioners for Foreign Missions, seguiram-se a American Baptist Foreign Mission Society (1882), a United Church of Canada (1886) e a Plymouth Brethren (1890).

9. AHU Angola, 2aS.2aR. p. 14, Ofício de 15/2/1890 que acompanha um telegrama de 7/12/1889, do Ministério da Marinha para o Governador Geral.

10. Nas suas cartas, Silva Porto afirmava a necessidade da ferrovia para o Bié, a fim de evitar espoliaçôes territoriais da parte das potências estrangeiras. Cf. Jornal de Moçâmedes, no $154,1 / 5 / 1890$.

11. Por contraste, citava-se a prática do governo britânico, que mandava "conduzir colonos à sua custa como, por exemplo, acontece em Demerara, e lhes dá auxílios muito superiores", atraindo, por esse meio também, colonos portugueses que preferiam outros destinos às colônias da África (AHU Angola, CG, p. 48, Ofício de 6/12/1878).

12. Sessão da Sociedade Propagadora de Luanda, realizada em 11/1/1882 (O Mercantil, 651, 26/1/1882).

13. Com efeito, os carros puxados a boi, introduzidos na Humpata pelos colonos bôers na década de 1880, embora constituíssem uma melhoria sensível, exigiam fretes caros que impossibilitavam a obtenção de margens de lucro compensadoras na venda dos produtos agrícolas do planalto em Moçâmedes (Jornal de Moçâmedes, $\mathrm{n}^{\circ}$ 164, $4 / 8 / 1891)$. Até 1890 , o custo do transporte do litoral a Lubango variava entre $\$ 950$ e $1 \$ 200$ (réis) por arroba de mercadoria; nesse ano, contudo, passou a $2 \$ 000$ devido à falta de bois e carros, desviados para a expedição a Bié (AHU Angola 2a S. 2a R. p. 14, Ofício de 4/9/1890).

Estudos Afro-Asiáticos, Ano 23, no 1, 2001, pp. 165-169 


\section{Aida Freudenthal}

14. Alguns anos antes fora feito um apelo à proteção inglesa pelos proprietários e negociantes do distrito de Moçâmedes, às voltas com revoltas de africanos que o "governo portuguez não queria ou não podia” reprimir (AHU Angola CG p. 48, Ofício de 15/5/1878 e 6/12/1878) e com uma "crise de braços", resultante da emancipação dos libertos (1875).

15. Uma corrente de opinião, claramente minoritária na colônia, advogava a criação de "estações civilizadoras" como pólos de autoridade militar, administrativa e de irradiação missionária, e ainda como esteios da dominação colonial em perspectiva (Sessão da Sociedade de Geografia de Loanda, 11/1/1882 apud O Mercantil, no 651, 26/1/1882). A propósito, veja-se o Decreto de Agosto de 1881, inspirado no neo-expansionismo da Sociedade de Geografia de Lisboa, que criava as referidas estações para propagação da "civilização e da influência européias". Os efeitos práticos limitaram-se à criação de algumas estaçōes em Cabinda e Lunda, entre 1884 e 1887 (Pélissier, 1986, v. I:207-8).

16. Os reis do Bailundu, Bié e Tchyaka coligaram-se e tornaram-se hostis aos portugueses (Chilcote, 1972:289).

17. Os casos mais exemplares ocorreram no Cazengo, Seles, Amboim e Moçâmedes (cf. Freudenthal, 1989:76, 80-89, 116).

18. Basta citar, como exemplo, um testemunho insuspeito, no final dos anos 1870: Serpa Pinto informa Andrade Corvo sobre a existência de tráfico de escravos em Caconda, Bié, Cunene e Ganguelas, dando razão às acusações de Cameron (ver Relatório de Serpa Pinto de 18/1/1878 apud AHU Angola CG p. 48). H. D. Carvalho testemunhou o mesmo fato em Lunda (1890, v. I:283-85).

19. Entre 14/12/1889 e 31/10/1891 foram exportados cerca de 3559 "contratados", segundo os mapas da Curadoria Geral de Angola (AHU Angola, 2aS. 2aR. p. 14 e 15). A carência de mão-de-obra para as fazendas era atribuída a esse recrutamento, tendo originado fortes protestos por parte dos agricultores de Pungo-Andongo e de outras regiôes (Boletim Colonial, no 4, 6/12/1891).

20. Na ferrovia em construção entre Cacuaco e Quifangondo, trabalhavam 800 homens contratados (O Mercantil, no 919, 17/3/1887).

21. Veja-se o processo da criação do distrito do Congo em 1885 em Pélissier (1986, v. I:257-61).

22. Para mais informações sobre os conflitos existentes, ver Angolana (v. II:686-87).

23. São relativamente numerosos os estudos publicados sobre esta questão. Ver, por exemplo, Chilcote (1972), Wheeler $(1970,1972)$, Dias $(1984,1986)$ e Bittencourt (1999).

24. Recorde-se que a imprensa africana se iniciou em 1881 com a publicação de $O$ Echo de Angola, em Luanda (Lopo, 1964:75). Alguns europeus participaram do protesto ao lado dos seus colegas africanos, sendo de realçar a ação de Urbano de Castro no seu jornal A Uniāo Áfrico-Portuguesa, Luanda 1882.

25. Entre eles, há a destacar individualidades como José de Fontes Pereira (1823-1891), José Arantes Braga (fal. 1885), Lino de Sousa Araújo (1847-1907?), Arcenio de Carpo (fal. 1890?), Cornélio de Castro Francina, Mamede Sant'Ana e Palma (fal. 1908), António J. do Nascimento (fal. 1902), Pedro da Paixão Franco (fal. 1911), Augusto

Estudos Afro-Asiáticos, Ano 23, no 1, 2001, pp. 166-169 
Silvério Ferreira (fal. 1915), Augusto T. Bastos (1872-1920?), A. J. Miranda, Francisco Castelbranco e Assis Júnior (1877-1960).

26. Na mesma linha de defesa das tradições culturais insere-se a criação de outras associações como a Filarmônica Africana, fundada em Luanda, em 1889 (O. Ribas, Izomba, 1965 apud Wheeler, 1972:73).

27. Na década de 1870 , o primeiro periódico a declarar-se abertamente republicano foi o Cruzeiro do Sul, de Luanda (no 12, 1/9/1873).

28. As reações que se seguiram à publicação deste apelo, tiveram eco na correspondência oficial (AHU Angola, 2aS. 1aR. p. 10, Ofício de 30/1/1890 apud Dias, 1984:85).

29. Para uma interpretação global do Ultimato, ver Alexandre (1979:189-93).

30. Ofício confidencial de Brito Capelo, de 30/1/1890, referido na nota 28

31. Após a derrota militar, foi-lhe imposta uma declaração de renúncia ao cargo, tendo sido aprisionado e deportado para Cabo Verde (AHU Angola, 2a ${ }^{\mathrm{a}}$. $1^{\mathrm{a}} \mathrm{R}$. p. 11, Ofício de 21/2/1891).

32. Referências a autos de vassalagem no Centro e Sul de Angola cf. AHU Angola, 2aS.

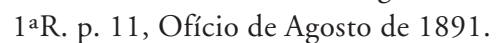

33. A revolta dos Humbi e Cuamatui em 1891, dirigida pelo chefe Luhuna, socorreu-se de armas vindas de Walvis Bay e do Transvaal (Jornal de Mossâmedes, $\mathrm{n}^{\circ} \mathrm{s}$ 164, 165, 167 e 168, de agosto a outubro de 1891).

\section{Fontes Primárias}

AHU - Arquivo Histórico Ultramarino, Angola. 2a Seção. $1^{a}$ Rep. Pastas 10 (1890), 11 (1891) e 15 (1891); 2a. Rep., Pastas 14 (1890) e 15 (1891); Correspondência de Governadores, Pasta 48 (1878).

\section{Periódicos}

Arauto Africano, O, Luanda 1889-90

Correio de Luanda, O, Luanda 1890-95

Desastre, O, Luanda 1889-1893

Farol do Povo, O, Luanda 1883-85

Futuro d'Angola, O, Luanda 1882-94

Jornal de Loanda, O, Luanda 1878-80

Jornal de Mossamedes, Moçâmedes 1881-1895

Mercantil, O, Luanda 1870-96

Muen'exi, Luanda 1889

União Áfrico-Portuguesa, A, Luanda, 1882-83.

Boletim Colonial, Lisboa 1891

Boletim da Sociedade Propagadora de Conhecimentos Geográfico-africanos. n.1.Luanda 1881

Estudos Afro-Asiáticos, Ano 23, no 1, 2001, pp. 167-169 
Aida Freudenthal

\section{Referências Bibliográficas}

ALEXANDRE, Valentim (1979), Origens do Colonialismo Português Moderno. Lisboa, s/e.

ANTÓNIO, Mário (1961), A Sociedade Angolana do Fim do Século XIX e um seu Escritor. Luanda, s/e.

BENDER, G. (1980), Angola sob Dominio Português - Mito e Realidade. Lisboa, Sá da Costa.

BITTENCOURT, Marcelo (1999), Dos Jornais às Armas. Trajectórias da Contestação Angolana. Lisboa, Vega.

BRUNSCHWIG, H. (1974), A Partilha da África Negra. São Paulo, s/e.

CARVAlHO, H. A. Dias de (1890), Descrição da Viagem à Mussumba do Muatiânvua. Lisboa, s/e.

CHILCOTE, Ronald (ed.) (1972), Protest and Resistance in Brazil and Portuguese Africa. Berkeley, University of California Press.

CLARENCE-SMITH, W. G. (1979), Slaves, Peasants, and Capitalists in Southern Angola. 1840-1920. Cambridge, Cambridge University Press.

DIAS, Jill (1984), "Uma Questão de Identidade: Respostas Intelectuais às Transformaçôes Econômicas no Seio da Elite Crioula da Angola Portuguesa entre 1870 e 1930 ”. Revista Internacional de Estudos Africanos, no 1, Lisboa.

(1986), "Changing Patterns of Power in the Luanda Hinterland". Paideuma, no 32, pp. 285-318.

FREUDENTHAL, Aida (1989), Arimos e Fazendas. A Transição Agrária em Angola (1850-75). Dissertação de Mestrado, Universidade Nova de Lisboa.

_ (2000), "A Utopia Angolense, 1880-1915". In A África e a Instalação do Sistema Colonial (c.1885-c.1930). Lisboa, IICT, pp. 561-572.

HAMILTON, Russell (1975), Literatura Africana, Literatura Necessária. I Angola. Lisboa, Sá da Costa.

HEINTZE, Beatrix. (1999), Ethnographische Aneignungen. Deutsche Forshungsreisende in Angola. Frankfurt, Lembeck.

ISAACMAN, A. e VANSINA, J. (1987), "Resistencia e Iniciativas Africanas en Africa Central, 1880-1914”. In Unesco, Historia General de Africa, Madrid, Unesco, vol. VII, cap. 8.

LOPO, Júlio de Castro (1964), Jornalismo de Angola: Subsídios para a sua História. Luanda, s/e.

OLIVEIRA, M. A. Fernandes (1990), Reler África. Coimbra, Universidade de Coimbra.

e COUTO, J. (dir.) (1968), Angolana. Luanda, IICA, 2 vols.

PELISSIER, René (1986), História das Campanhas de Angola. Lisboa, s/e. 2 vols.

PINTO, F. Latour Veiga (1972), Le Portugal et le Congo au XIXe. Siècle. Paris, s/e.

SANTOS, Eduardo dos (1986), A Questão do Barotze. Lisboa, IICT.

SANTOS, Maria Emília M. (1978), Viagens de Exploração Terrestre dos Portugueses em África. Lisboa, JICU.

SELVAGEM, C. e GALVÃO, H. (1953), O Império Ultramarino Português. Lisboa, s/e., 2 vols.

TEIXEIRA, Nuno S. (1990), O Ultimatum Inglês. Lisboa, s/e.

Estudos Afro-Asiáticos, Ano 23, no 1, 2001, pp. 168-169 
WHEELER, D. (1970), "An Early African Protest". In Rotberg e Mazrui, The Tradition of Protest in Black Africa. Oxford, Oxford University Press

_ (1972), "Origins of African Nationalism in Angola: Assimilado Protest Writing, 1859-1929”. In R.Chilcote, Protest and Resistance in Brazil and Portuguese Africa. s/l, s/e.

e PÉLISSIER, R. (1978), Angola (2a ed.). New York, Praeger.

Estudos Afro-Asiáticos, Ano 23, no 1, 2001, pp. 169-169 